\title{
Erişilebilirlik ve Sosyal Etkileşim iliş̧kisinin Kamusal Alanlarda Değerlendirilmesi: Çukurambar Mahallesi Örneği
}

\author{
Pelin ŞAHIN KÖRMEÇLi ${ }^{1 *}$ (D) Aysel USLU 2 (D) \\ ORCID 1: 0000-0003-4772-8202 \\ ORCID 2: 0000-0002-1158-7551 \\ ${ }^{1}$ Çankırı Karatekin Üniversitesi, Orman Fakültesi, Peyzaj Mimarlığı Bölümü, 18200, Çankırı, Türkiye. \\ ${ }^{2}$ Ankara Üniversitesi, Ziraat Fakültesi, Peyzaj Mimarlığı Bölümü, 06120, Ankara, Türkiye. \\ *e-mail: pelinsahin@karatekin.edu.tr
}

Öz

Hızlı kentleşme sonucu artan nüfusla birlikte kentlerde oluşan fiziksel ve sosyal sorunları çözmek için tüm bireylerin kent yaşamına katılabileceği ve eşit alan kullanımını sağlayan kamusal alan tasarımına ihtiyaç vardır. Bu çalışmanın amacı; kamusal alanlarda sosyal etkileşim ve erişilebilirlik ilişkisini irdeleyerek, bu ilişkiyi destekleyen kapsayııı tasarım kriterlerini belirlemektir. Çalışma alanı olarak seçilen farklı tipolojik özellikteki kamusal alanlara sahip Ankara Çukurambar Mahallesi'nde mekân dizimi, zihin haritalama, anket, delphi yöntemleriyle oluşturulmuş model değerlendirilmiştir. Çalışma alanında ilk aşamada mekân dizimi yöntemi ile fiziksel açıdan yoğun kullanıma sahip akslar, zihin haritalama yöntemiyle de bireylerin kullandığı alanlar tespit edilerek veriler örtüştürülmüştür. Diğer aşamada ortaya çıkan yoğun kullanıma sahip kamusal alanlarda, sosyal etkileşimi ve erişilebilirliği destekleyen mekânsal kalite parametreleri kullanıcılar ve uzmanlar tarafından değerlendirilmiştir. Araştırma sonucunda, başta yürünebilirlik olmak üzere, kamusal mekân kalitesinin, ulaşım durumunun, demografik özelliklerin, sosyal ve psikolojik faktörlerin sosyal etkileşim ve erişilebilirliği destekleyen kriterler olduğu saptanmıştır.

Anahtar Kelimeler: Ankara, kamusal alan, mekân dizimi, mekân kalitesi, zihin haritalama

\section{Evaluation of Accessibility and Social Interaction Relationship in Public Spaces: Case of Çukurambar Neighborhood}

\begin{abstract}
There is a need for public space design in which individuals can participate in urban life and provide equal space use to solve physical and social problems with increasing population as a result of rapid urbanization. The research aim is to examine relationship between social interaction and accessibility in public spaces and determine inclusive design criteria that support this relationship. Çukurambar Neighborhood, which has different typological public spaces selected as study area, was evaluated with space syntax, mind mapping, questionnaire, delphi methods. Firstly, intensive space use finded out by using spatially integrated roads in space syntax and user preferences in mind mapping methods. Secondly, spatial quality parameters supporting social interaction and accessibility were evaluated by users and expert in intensive space use. As a result of research, it was determined that walkability, quality of public space, transportation systems, social, psychological factors are main parameters that support social interaction and accessibility.
\end{abstract}

Keywords: Ankara, public space, space syntax, quality of space, mind mapping

Citation/Atıf: Şahin Körmeçli, P. and Uslu, A. (2021). Erişilebilirlik ve sosyal etkileşim ilişkisinin kamusal alanlarda değerlendirilmesi: Çukurambar Mahallesi örneği. Journal of Architectural Sciences and Applications, 6 (2), 414427.

DOI: https://doi.org/10.30785/mbud.934288 


\section{Giriş}

Kentlerde kamusal alanlar, bireylerin etkileşim içerisinde bulunduğu yaşayan organizmalardır. Kamusal alanlardaki sokaklar, meydanlar, parklar, çocuk oyun alanları gibi farklı tipolojideki mekânlar bireylerin etkin ve sosyal olarak bir arada olması açısından önemlidir (Goličnik ve Thompson, 2010). Son zamanlarda hızlı kentleşme süreci sonucunda bireylerin sosyalleşebildiği erişilebilir alanlar azalmaktadır. Bu kapsamda tüm bireylerin birlikte olacağı ve eşit alan kullanımını sağlayan yani erişilebilirliği ve sosyal etkileşimi destekleyen tasarım kriterlerine intiyaç vardır. Fiziksel erişilebilirliği ve sosyal etkileşimi sağlayan tasarım özellikleri herkes için kullanılabilir alanlar yaratarak toplumun bütünleşmesine katkıda bulunmaktadır.

Kentin yaşam alanları olan kamusal alanlar, kentin sosyal, ekonomik ve kültürel faaliyetlerinin gerçekleştirilmesinde rol oynamaktadır (Kaplan ve Öztürk, 2004). Kamusal alanlar bireylerin sosyal etkileşim kurmasına imkân sağlamaktadır. Kamusal alanların sosyal rolü; "halk yaşamı için bir alan, farklı sosyal grupların toplanma yeri, toplumdaki imajın görüldüğü bir mekân, kentsel faaliyetler ve iletişim sistemleri arasındaki kısım" olarak vurgulanmaktadır (Thomas, 1991). Kentsel açık ve yeşil alanların içerisinde yer alan kamusal alanları Carr, Francis, Rivlin ve Stone (1992), insanların grup veya bireysel aktivitelerde bulunduğu erişilebilir yerler olarak tanımlamaktadır. Kentsel açık alan tipolojileri, parklar, meydanlar, anıtlar, pazarlar, caddeler, çocuk oyun alanları, kamusal açık mekânlar, yeşil yollar ve çizgisel park yollar, kentsel doğal yaşam alanları, avlular, iç mekânlar, komşuluk üniteleri ve su kıyısı alanları şeklinde sınıflandırılmaktadır (Carr ve diğerleri, 1992; Özyılmaz, 2009). Kentsel alanların tipolojilerinin incelenmesinde Kevin Lynch'in kent imgesi bileşenlerinden (yollar, kenarlar, bölgeler, düğüm/odak noktaları, işaret ögeleri) yararlanılmaktadır (Lynch, 2010). Kent imgelerinin algılanabilirliği ile kişinin hareketi arasında ilişki kuran Stevens' ın (2006) çalışmasında kent imgelerinin mahalle ölçeğindeki karşılıkları olarak yollar, yolların kesişim noktaları, sınırlar, kentsel donatılar, kentsel geçiş alanları verilmiştir. Araştırmada kent imgelerinin mahalle ölçeğindeki sınıflaması dikkate alınmaktadır.

Kentsel açık alan tipolojileri içerisinde yer alan, sosyal ve kültürel yaşam alanı olan mahalleler, ilk kez Perry tarafından 20. yy'ın başında, konut ve şehir merkezlerindeki ulaşım problemini çözmek için ortaya çıkmıştır (Eisner, Gallion ve Eisner, 1993). Günümüzde mahalle, fiziksel bir alan dışında sosyolojik, kültürel ve ekonomik boyutları olan canlı organizmalar olarak tanımlanmaktadır (Johnson, 2002). Mahallelerde, sağıklı sosyal ilişkilerin kurulması ve homojen toplumların oluşması kapsayıcı tasarım açısından önemlidir. Bu kapsamda kentlerde insanların sosyal yaşam alanı olan mahallelerin mekân kalitesinin irdelenmesi gerekir. Mekân kalitesi, kamusal alanların iyileştirilmesinde önemli yere sahiptir ve pek çok araştırmada farklı göstergelerle değerlendirilmektedir. Hesham (2015), kamusal mekân kalitesinin alan kullanımını belirleyen faktörden biri olduğunu ortaya koymuştur. Whyte (2000), başarılı kamusal alanların üretilmesine yönelik yaptığı araştırmalarında sürdürülebilir kamusal mekânların tasarlanması için sosyallik, kullanım ve aktiviteler, erişim ve bağlantılar, konfor ve imaj olmak üzere dört temel parametreyi esas almaktadır (Project for Public Spaces, 2019). Kentlerde bireylerin kamusal alanlardan sosyal ve fiziksel anlamda fayda sağlayabileceği mekân kalitesi parametreleri geliştirilmelidir.

Kamusal alanların sürdürülebilirliğinde sosyal etkileşimin sağlanması, sosyal bütünleşmeyi ve uyumu beraberinde getirmektedir. Kamusal alanlarda sosyal etkileşimi destekleyen pek çok etmen yer almaktadır. Yapılan araştırmalarda Gökten (1991) sosyo-kültürel yapıya ilişkin kuralların, Şensoy (2012) bireylerin demografik özelliklerinin ve dış mekân kullanımlarının, Anton ve Lawrence (2014) yaşadığı yerdeki ikamet etme süresinin, Lang (1987) kültürel alt yapılarının sosyal etkileşimi değiştiren etmenler olduğunu ifade etmişlerdir. Diğer araştırmalarda ise Erdönmez ve Akı (2008) açık mekânda geçirilen zamanın ve mekân kalitesinin, Gehl (1987) düşük hızdaki araç sirkülâsyonunun, Pulat (1996) komşuluk ilişkilerinin, Garip (2010) psikolojik belirleyicilerin (mahremiyet gibi), Rivlin (1994) aktivitelerin sosyal etkileşimi desteklediğini belirtmişlerdir. Ayrıca bireylerin mekândaki konumları (yakınlık, erişme vb.) sosyal etkileşimde belirleyici olmaktadır (Demir, 2006). Sosyal deneyimlerin artmasında konut çevresindeki yürümeyi destekleyen sokak tasarımları etkili olmaktadır (Ewing ve Clemente, 2013). Bu nedenle bireylerin yaya olarak düşünülmesi ve yürüme mesafesindeki açık ve yeşil alanlarda erişilebilirlik konusunun dikkate alınması önemlidir. 
Erişilebilirlik fiziksel, sosyal, psikolojik, kültürel ve ekonomik boyutları olan bir kavramdır. Kamusal alanlarda yaşanabilirliğin belirleyicilerinden biri olan yürünebilirlik, yol koşulları, arazi kullanım deseni, güvenlik ve konfor gibi etmenlerle yayalara kolaylık sağlamaktadır (Ak, 2018). Bir yaya günlük intiyaçlarını karşılamak amacıyla 10 dakika süren 600 metre yürüme mesafesindeki yere ulaşabilmektedir (Hildebrand, 1999). Yürünebilir açık ve yeşil alanlara erişimde bu mesafe dikkate alınmalıdır. Farklı tipolojilerdeki kamusal alanların (oyun alanı, meydan, parklar vb.) varlığı yürünebilirliği artıran faktördür (Lambert, 2005). Bu kapsamda kamusal alanlardaki çeşitlilik ve kullanımlar erişilebilirliği desteklemektedir. Kamusal alanlarda erişilebilirliği sağlayan diğer kriter, sokak ve cadde dokusu yani yolların oluşturduğu ağ sistemidir. Alan kullanımında yollar; grid formlu, paralel-bölünmüş, paralel-çarpık, spiral formlu çıkmaz, doğruya saplanarak dönen olarak sınıflandırılmaktadır (Southworth ve Own, 1993). Yolların kesişim sayısı ne kadar çoksa erişilebilirlik de yüksek olmaktadır (Özbil, Yeşiltepe ve Argin, 2015). Diğer yandan yol ağlarının bağlantılılığı çoksa, yürünebilirlik ve erişilebilirlik de yüksek olmaktadır (Southworth, 2005). Konut çevresindeki kamusal alanlarda düşük hızda araç sirkülasyonu insanların dış mekâna yönlenmesini sağlamaktadır (Gehl, 1987). Mekân kalitesi parametrelerinden olan erişim; yolların bağlantılılığına ve yaya, özel araç, toplu taşıma hizmetlerinin olduğu ulaşılabilirlik kriterlerine göre değerlendirilmektedir (Uzgören ve Erdönmez, 2017). Kentlerde herkes için erişilebilirliğin sağlanması için yapısal duruma ilişkin özellikler (yaya yolları, kaldırımlar gibi), kentsel donatılar bireylere engel oluşturmayacak şekilde ve belirtilen teknik standartlara (Kaplan vd., 2011) uygun olarak düzenlenmelidir. Erişilebilirliği ve sosyal etkileşimi destekleyen bu kriterlerin göz önünde bulundurulduğu kamusal alan tasarımı kapsayıcı çevreler sunmaktadır.

Kentlerde farklı özellik ve yetiye sahip bireyler bir arada yaşamaktadır. Insanların ihtiyaçları düşünülerek herkesin toplumsal yaşama katıldığı alanlar tasarlanmalıdır. Kent sakinlerinin sosyal olarak bir arada olduğu ve erişilebilir kamusal alanlar kapsayıcı tasarıma hizmet etmektedir. Kamusal alanların sürdürülebilirliği ve yaşanabilirliği açısından kapsayıcı tasarım yaklaşımı temel alınması gerekmektedir. Bu kavramın felsefesinde, tasarımın girdiği her yaşam alanında, toplumdaki tüm bireylerin düşünülerek tasarımın gerçekleştiği ölçeğe ilişkin bu yaklaşımın uygulanması yer almaktadır (Evcil, 2014). Kapsayıcı tasarım, her durumda ve herkese eşit, erişilebilir, kullanılabilir çevre, mekân yapı elemanı, ekipman ve ürün sunması açısından diğer tasarımlardan farklıdır (Hacıhasanoğlu, 2003). "Erişilebilirlikle ilgili standartların, tasarıma sonradan eklemek yerine tasarım sürecine dâhil edildiğinde ortaya çıkan ve her kullanıcı için eşit kullanımı öngörerek, toplumsal eşitliği ve insan onurunu koruyan, sosyal etkileşimi destekleyen tasarım" kapsayıcı tasarım olarak belirtilmiştir (Kaymaz, 2015). Bu bağlamda kentlerde herkese erişilebilir ve sosyal çevreler sunan kapsayıcı tasarım yaklaşımı hedef alınarak, bu hedefi destekleyen alt parametreler araştırılmıştır. Çalışma kapsamında kentlerin gerek fiziksel gerekse sosyal yönü ile farklı bireylere yönelik olarak nasıl tasarlanması gerektiğine dair mekânsal kalite parametreleri irdelenmiştir. Araştırmada kamusal alanlarda sosyal etkileşim ve erişilebilirliği destekleyen kapsayıcı tasarım kriterlerinin çıkarılması amaçlanmaktadır. "Kamusal alanlarda sosyal etkileşimin ile erişilebilirlik arasında doğrusal bir ilişki vardır" araştırmanın hipotezini oluşturmaktadır. "Kamusal alanlarda sosyal etkileşim ve erişilebilirlik ilişkisini destekleyen kapsayıcı tasarım kriterleri nelerdir?" araştırma sorusundan yola çıkılmışır. Örneklem alanı olarak farklı tipolojideki kamusal alanları içeren, kentsel dönüşüm süreci geçirmiş ve yoğun alan kullanıma sahip olan Ankara Çukurambar Mahallesi'nde çalışılmıştır. Çalışmanın ilk aşamasında alanın fiziksel erişilebilirliğini belirlemede mekân dizimi yöntemi, bireylerin sosyal etkileşim alanlarını belirlemede zihin haritalama yöntemi kullanılmıştır. Bu iki yöntemden elde edilen veriler birleştirilerek fiziksel ve sosyal anlamda yoğun kullanıma sahip alanlar ortaya çıkarılmıştır. Diğer aşamada yoğun kullanıma sahip bu kamusal alanlarda, sosyal etkileşime ve erişilebilirliğe ilişkin mekânsal kalite parametreleri uzman ve kullanıcılar tarafından değerlendirilmiştir. Son aşamada, tüm nitel ve nicel parametreler istatistiksel olarak değerlendirilerek sosyal etkileşim ve erişilebilirlik ilişkisinin etki düzeyi ortaya koyulmuş ve bu ilişkiyi destekleyen tasarım kriterleri elde edilmiştir. Kapsayıcı tasarıma hizmet eden bu kriterler kentsel yaşam kalitesine, insan sağlığına ve yaşanabilir kentlerin oluşturulmasında bilimsel verilere katkı sağlayacaktır. 


\section{Materyal ve Yöntem}

\subsection{Materyal}

Çalışma alanı Ankara kent merkezinin güneybatısında yer alan Çukurambar Mahallesi'dir. Alanın doğusunda Konya yolu, güneyinde Eskişehir yolu ve batısında Malazgirt Bulvarı yer almaktadır (Şekil 1). Alan çevresindeki yoğun kullanıma sahip akslarla kent merkezine bağlanmaktadır. Çukurambar Mahallesi ticaret, iş merkezleri ve konut alanlarının olduğu bölgededir.
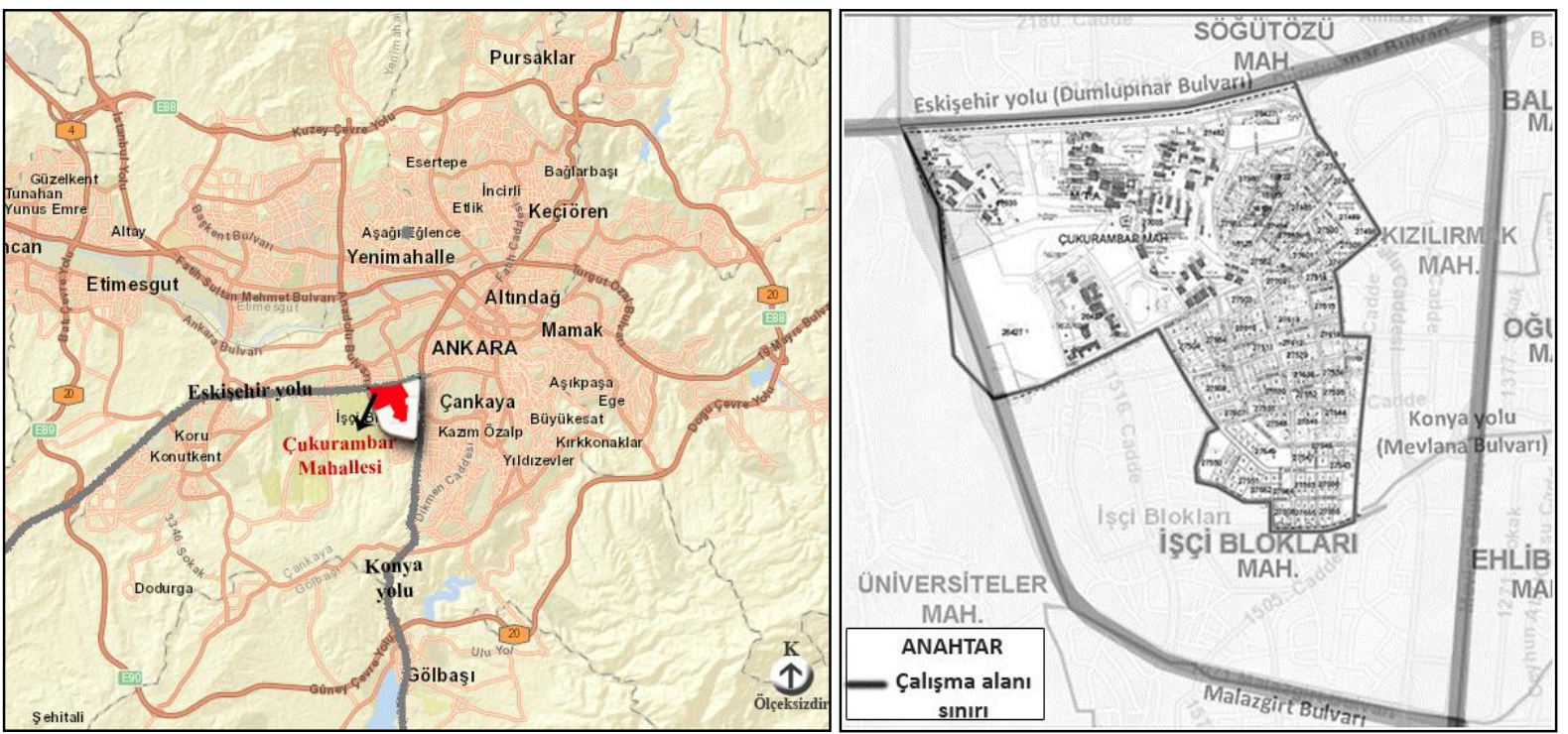

Şekil 1. Çalışma alanının konumu ve yakın çevresi (Çankaya Belediyesi, 2018).

Mahallenin sosyal etkileşimi için önemli olan parklar, meydanlar, caddeler, sokaklar, yol aksları, oyun alanları gibi farklı tipolojideki kamusal alanları içermesi mekânsal değişimi ölçmek için fırsat yaratmaktadır. Ayrıca Çukurambar Mahallesi'nin hızlı bir kentsel dönüşüm süreci geçirmiş olması da fiziksel ve sosyal yapının irdelenmesi açısından potansiyel oluşturmaktadır. Konu ile ilgili yapılmış yerli ve yabancı kaynaklar, Çukurambar Mahallesi ile ilgili ölçekli plan, harita, hava fotoğrafları, raporlar, arazi etüt çalışmaları, kişilerle yapılan görüşmeler araştırmanın materyallerini oluşturmaktadır. Çalışma ile ilgili verilerin sayısal olarak değerlendirilmesinde Graph Commons, DeptmapX, AutoCAD, SPSS 21 programları kullanılmıştır.

\subsection{Yöntem}

Alanın fiziksel erişilebilirliğini belirlemede "Mekân dizimi (Space Syntax)" ve bireylerin sosyal etkileşim alanlarını belirlemede "Zihin Haritalama (Mind Mapping)" yöntemi kullanıımıştır. Mekânsal yapıyı sosyal yapıyla ilişkilendirerek alandaki erişilebilirliğin ölçülmesi ve Çukurambar Mahallesi'ndeki alanların kullanım potansiyeli mekân dizimi yöntemiyle çözümlenmiştir. Mekân dizimi, bina ölçeğinden kent ölçeğine kadar mekânın fiziksel yapısı, kullanım biçimi, yaya hareketleriyle mekânsal çevre ilişkilerini sayısal yöntemle değerlendirerek bunu sosyal yapıyla ilişkilendirmektedir. Çalışmada bu yöntemle mekânsal analiz yapılarak yoğun kullanıma sahip akslar belirlenmiştir. Mekân dizimi yöntemi diğer yandan, yapılaşmış çevreye sayısal tanımlar getirmekle birlikte, kullanıcı hareketlerine ve kültürel faktörlere yeni çerçeveler çizerek, fiziksel ve sosyal yapı arasındaki ilişkiyi ispatlamaktadır (Özbek, 2007). Mekân dizimi çalışmalarında ilave olarak kullanıcı hareketleri, gözlem, anket gibi yöntem ve teknikler de kullanılmaktadır (Hillier ve Hanson, 1984; Tutal, 1999). Zihin haritalama yöntemiyle araştırmada bireylerin en çok kullandığı mekânların etki alanları saptanmıştır. Algı, deneyim ve hafıza alanındaki çözümlemeler, bireylerin mekânlara ilişkin aklındaki çizimleriyle ifade ettikleri zihin haritalarıyla belirlenebilmektedir (Çanakçıoğlu, 2016). Çalışmada bireylerin yaşadığı yeri düşünerek Çukurambar Mahallesi'nde kullandığı alanları çizmesi istenmiş ve bu çizimler değerlendirilmiştir. Elde edilen veriler doğrultusunda sosyal etkileşime ve erişilebilirliğe ilişkin mekânsal kalite parametreleri, uzmanlar ve kullanıcılar tarafından kontrol edilmiştir. Uzman değerlendirmesinde delphi tekniği, kullanıcı değerlendirmesinde ise anket tekniği kullanılmıştır. Anketler Çukurambar Mahallesi'nde yaşayan ve çalışan kişilere yapılmıştır. Ankette; bireylerin kişisel özellikleri, mahallede ikamet etme 
süresi ve yaşama sebebi, komşuluk ilişki düzeyi, etkileşimde olduğu kişiler, evinden yürüdüğü maksimum uzaklık, hangi alanları ne sıklıkla kullandıkları, kullanım amaçları sorulmuş ve mekânsal kalite parametrelerinin likert ölçekte değerlendirilmesi istenmiştir. Bu parametreler kamusal alanlarda mekân kalitesinin dört anahtar özelliğini taşıyan Uzgören ve Erdönmez (2017)'nin çalışmasındaki mekânsal kalite bileşenleri ve sosyal etkileşim ile erişilebilirliği destekleyen literatür araştırmalarıyla geliştirilmiştir. Sonuçta elde edilen tüm veriler ilişki testleriyle analiz edilmiş, her değişkenin birbiri üzerindeki etkisi SPSS programında değerlendirerek sosyal etkileşimi ve erişilebilirliği destekleyen kapsayıcı tasarım kriterleri çıkarılmıştır.

\section{Bulgular ve Tartışma}

\subsection{Mekânsal Analiz}

Çukurambar Mahallesi İmar Planı'na göre önce alandaki ada ve parseller ortaya çıkarılmış daha sonra mevcut yollara göre çizilen aksiyel harita oluşturulmuştur. Aksiyel harita kentsel açık alanlarda arazi kullanım dokularının sayısal olarak çıkarılmasında yol göstericidir. Aks haritasında en uzun ve kesintisiz akslar harita üzerinde gösterilmektedir. Aks haritasına göre programda alandaki grid aksiyalite değeri hesaplanmıştır. Grid aksiyelitenin hesaplanması için kullanılan formül aşağıdaki gibidir (Hillier ve Hanson, 1984).

\section{Grid aksiyelite (grid axiality) $=($ VIx 2)+2 /L (I: Yapı adaları sayısı L: Aks sayısı)}

Grid aksiyalite 0 ile 1 değeri arasında olup 0,25 üzerindeki değerler grid sistem dokularını, 0,15 altındaki değerler gridal sistemden uzaklaşma değerini belirtir (Özbek, 2007). Çukurambar Mahallesi'nde grid aksiyalite değeri 0,25 değerinden yüksektir ve gridal sistem dokusuna sahiptir. Aks haritasının yorumlanmasından sonra oluşturulan bütünleşme paftasında her bir aksın mekânsal bütünleşme değerleri hesaplanmıştır. Bu hesaplamalara göre sayısal olan bütünleşme değeri yüksek olan akslar erişilebilirdir. Şekil 2'de Çukurambar Mahallesi mekânsal bütünleşme haritası görülmekte olup bu değer mor renkten kırmızıya göre artmaktadır.

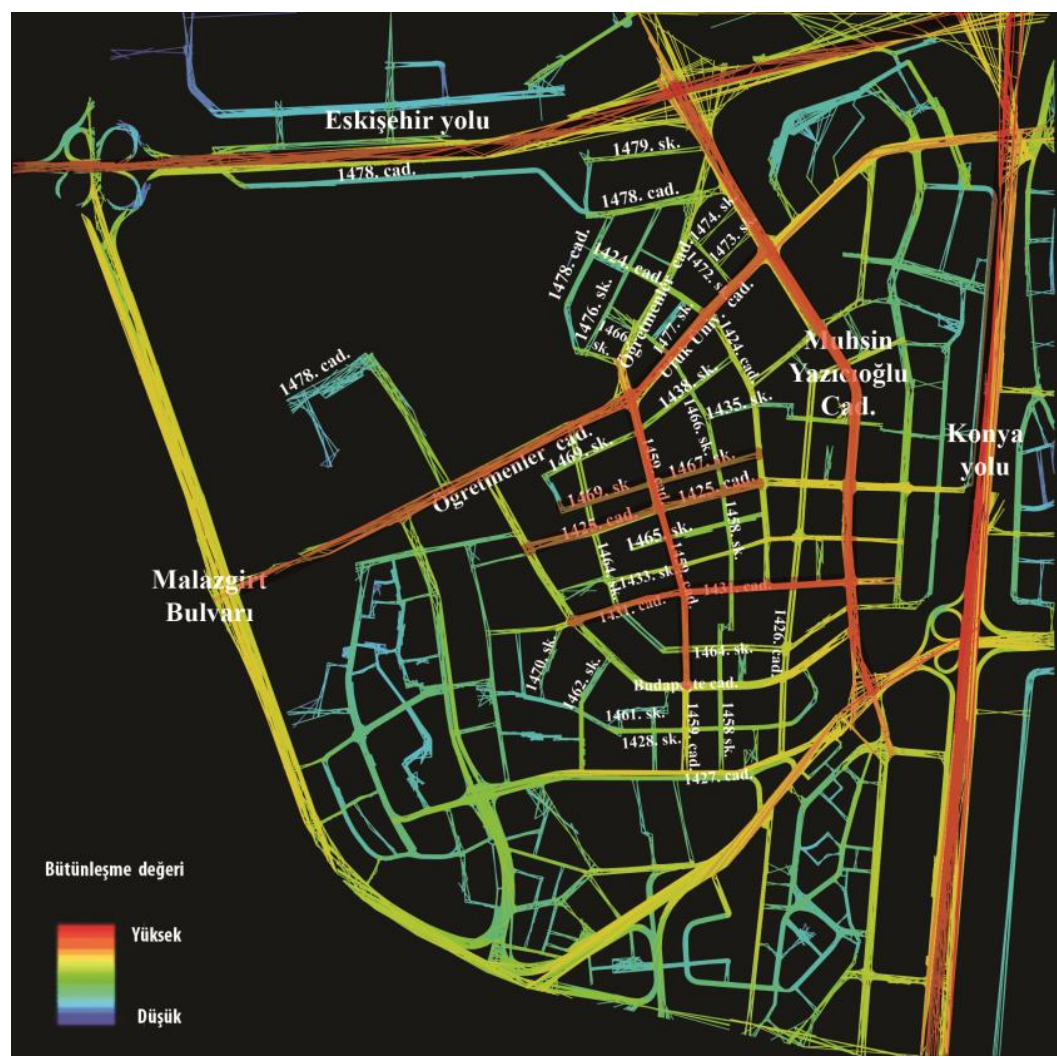

Şekil 2. Çukurambar Mahallesi ve yakın çevresi mekânsal bütünleşme haritası

Bütünleşme haritasına göre Konya yolu, Eskişehir yolu, Malazgirt Bulvarı ve 1427. Cadde orta derecede bütünleşme değerine sahiptir. Muhsin Yazıcıoğlu Caddesi, Öğretmenler ve Ufuk Üniversitesi Caddesi, 1425. Cadde, 1431. Cadde ve 1459. Cadde (kuzey kısmı) yüksek derecede bütünleşme değerindedir. 
Bütünleşme derecesi yüksek aksların daha çok kesişim noktasının olduğu görülmektedir. Yüksek ve orta derecede bütünleşme değerine sahip olan bu aksların yaya ve taşıt kullanım potansiyeli çoktur. Mekânsal analize göre Çukurambar Mahallesi'nde günümüzde yoğun konut dokusunun oluşturduğu gridal sistemin bulunduğu alanın kullanım ve erişilebilirlik değeri yüksektir. Diğer aşamada bütünleşme haritasında yüksek değere sahip olan alanların zihin haritalarından elde edilen sonuçlarla ilişkisi irdelenmiştir.

\subsection{Zihin Haritalarının Değerlendirilmesi}

Kullanıcıların çizdiği zihin haritalarına göre her bir ilişkinin (Kişi-yol, kişi-park,) ağ haritası oluşturulmuştur. Ağ haritasında; merkezi, dolaylı aktörler, yoğun kullanıma sahip alanlar ortaya çıkmaktadır ve sosyal bağlantılar görülebilmektedir. Bu bağlantıları çözümlemek için kümelenme ve merkeziyet derecesi değerlerine bakılmıştır. Merkeziyet derecesi, alandaki kullanımların yoğunluğu ve erişilebilirlik durumunu, kümelenme yüzdesi ise erişilebilirlik açısından noktanın kullanımlar içerisindeki konumunu ve sosyal etkileşim düzeyini göstermektedir. Oluşturulan ağ haritasında, sosyal etkileşimi yüksek mekânsal kullanımlar belirlenerek bu alanların erişilebilirlik düzeyleri değerlendirilmiştir. Zihin haritalarına göre oluşturulan ağ haritasında Uğur Mumcu Parkı, Muhsin Yazıcıoğlu Caddesi ve Teoman Öztürk Parkı'nın mekânsal kullanım değeri yüksektir (Şekil 3).

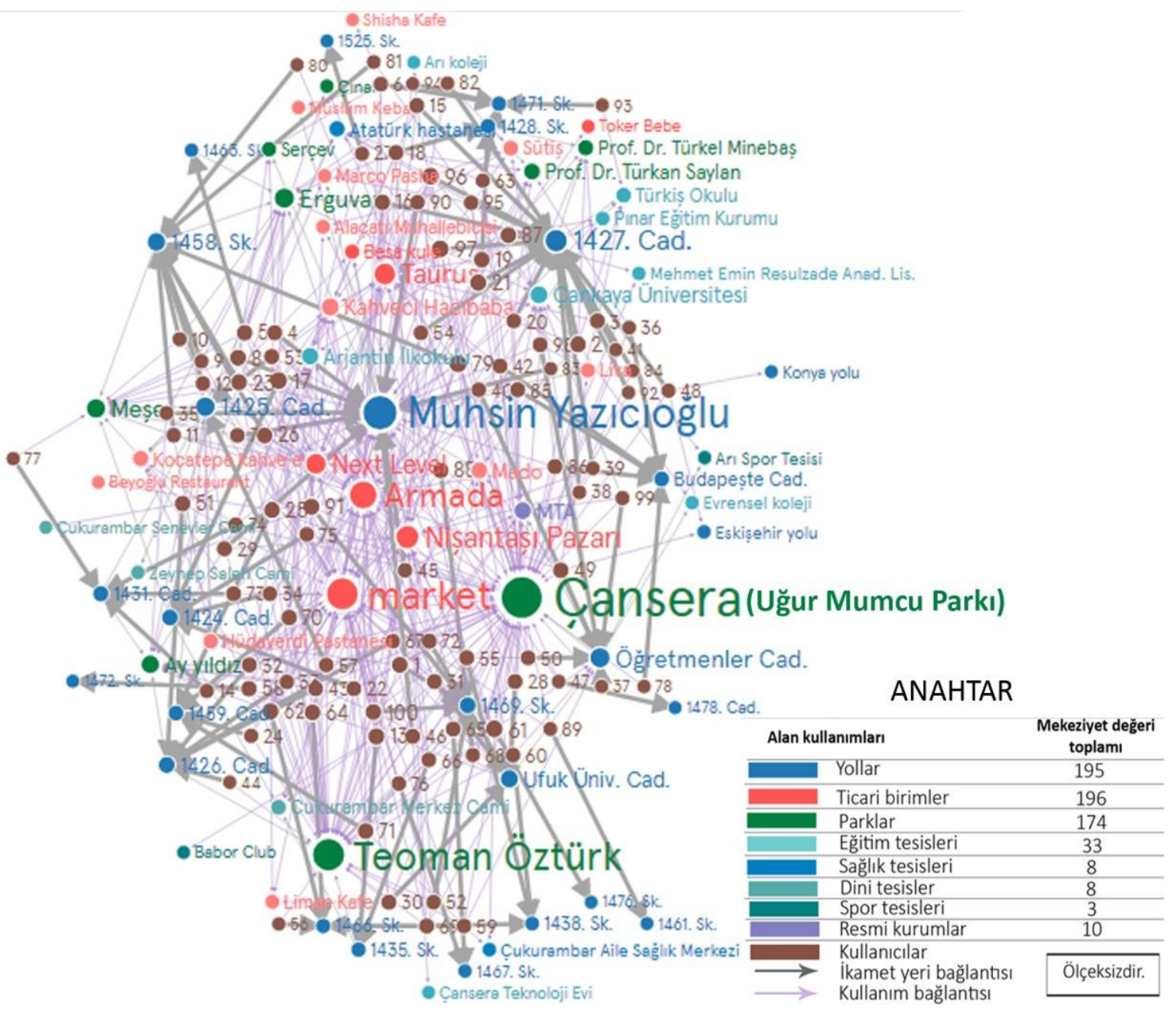

Şekil 3. Katılımcıların zihin haritalarına göre oluşturan ağ haritası

Zihin haritalarından elde edilen ağ haritasında alan kullanımını belirlemek için her mekânın merkeziyet derecesi değerlendirilmiştir. Mahallede yaşayan kişilerin \%37'si yolları, \%28'si ticari birimleri, \%13'ü parkları, \%11'i eğitim tesislerini \%3'ü spor alanlarını, \%3'ü sağlık tesislerini, \%4'ü dini tesisleri ve \%1'i resmi kurum alanlarını kullanmaktadır. Bireylerin kullanım alanları ticari birimler ve yollar üzerinde yoğunlaşmaktadır. Sosyal etkileşim düzeyine bakıldığında parklar \%30 ile en yüksek oranda, daha sonra \%24 oranda ticaret ve ulaşım alanlarının, \%6 oranda eğitim tesislerinin olduğu görülmüştür. Zihin haritalarının değerlendirmesinde Muhsin Yazıcıoğlu Cad., 1425. Cad., 1427. Cad. ve Öğretmenler ve 
Ufuk Üniversitesi Cad. merkeziyet değerleri yüksek değerde olup bu akslar mekân dizimi yönteminden elde edilen bütünleşme paftasındaki yoğunluklu alanlarla örtüşmektedir. Mekân dizimi yönteminde yoğun kullanıma sahip akslar ile zihin haritalama yönteminden elde edilen kamusal alanlar arasında anlamlı bir ilişkinin olduğu ortaya çıkmıştır.

\subsection{Mekânsal Kalite Parametrelerinin Değerlendirilmesi}

\subsubsection{Uzman değerlendirmesi}

Uzman değerlendirmesinde yüz yüze görüşme yapılmış, görüşülen kişi sayısı uzlaşma sağlanana kadar artırılmış, 12 kişide uzlaşma sağlanmış ve sonuçlar değerlendirilmiştir. Sosyal etkileşimi ve erişilebilirliği destekleyen mekânsal kalite parametrelerinin 5'li likert ölçekte puanlanması istenmiştir. Bu parametrelerin oluşturduğu ölçeğe yapılan güvenilirlik analizinde kullanılan ölçekte yer alan maddelerin iç tutarlıık katsayılarının (Cronbach Alpha) değeri 0.671 olup ölçek değerlendirmede yeterlidir (Şahin, 2001). Delphi anketinin analizi için yapılan uygulamada istatistikler kullanılarak çeyrekler arasındaki genişliğin azalıp azalmadığına bakılmıştır. Çeyrekler arası genişliği 1.2' den az çıkan maddeler, uzlaşma maddeleri olarak kabul edilmektedir (Zeliff ve Heldenbrand, 1993). Hesaplamalar için aritmetik ortalama, standart sapma, meydan ve çeyrekler arasındaki fark (ÇAF) değerleri kullanılmıştır. Delphi tekniğiyle uzlaşma konusunda yapılan çalışmalarda farklı derecelerdeki likert ölçekleri kullanılmaktadır. 7'li likert ölçeği için belirtilen uzlaşma ölçütleri bu çalışmada kullanılacak olan 5'li likert ölçeğine göre uyarlanmıştır (Çizelge 1).

Çizelge 1. Delphi tekniğindeki uzlaşma ölçüleri (Şahin (2009)'dan uyarlanmıştır.)

\begin{tabular}{cc}
\hline Uzlaşma & Uzlaşma göstergesi \\
\hline Ölçüte sahip & Eğer medyan $\geq 3,57$ ve ÇAF $\leq 1,07$ ise \\
& Eğer medyan $\geq 3,57$ ve ÇAF $\leq 1,07$ ve $3-5$ frekansı $\geq \% 70$ ise \\
\hline Ölçüte sahip değil & Eğer medyan $\leq 2,14$ ve ÇAF $\leq 1,07$ ise \\
& Eğer medyan $\leq 2,14$ ve ÇAF $\leq 1,78$ ve $1,5-3$ frekansı $\geq \% 70$ ise \\
\hline
\end{tabular}

Uzmanların değerlendirmelerine göre, sosyal etkileşim ve erişilebilirliği geliştirmede yürünebilirliğin temel kriter olduğu ortaya çıkmıştır. Yürümeyi destekleyen sokak tasarımları, yaya yollarının yeterliliği, yürüme mesafesindeki açık ve yeşil alanlar ve kamusal mekân kalitesi hem sosyal etkileşimi hem de erişilebilirliği destekleyen parametrelerdir. Nitelikli açık ve yeşil alan miktarı, kentsel donatıların varlığı, özel araç park yeri, nüfus yoğunluğu, dış mekânda geçirilen zaman ve psikolojik faktörler sonradan eklenen uzlaşma maddeleridir (Çizelge 2).

Çizelge 2. Delphi anket sonuçlarına göre uzlaşma maddeleri

\begin{tabular}{|c|c|}
\hline \multicolumn{2}{|c|}{ Uzlaşma Maddeleri } \\
\hline $\begin{array}{l}\text { Sosyal etkileşimin oluşumunu } \\
\text { destekleyen parametreler }\end{array}$ & $\begin{array}{l}\text { Erişilebilirliğin oluşumunu } \\
\text { destekleyen parametreler }\end{array}$ \\
\hline $\begin{array}{l}\text { Bireylerin yaşadığı yerdeki komşuluk ilişkileri } \\
\text { Bireylerin kültürel altyapıları ve demografik özellikleri }\end{array}$ & $\begin{array}{l}\text { Toplu taşımacılık hizmet } \\
\text { yeterliliği }\end{array}$ \\
\hline $\begin{array}{l}\text { Bireylerin dış mekânda geçirdikleri zaman } \\
\text { Yürümeyi destekleyen sokak tasarımları }\end{array}$ & $\begin{array}{l}\text { Yaya yollarının ve kaldırımların } \\
\text { yeterliliği }\end{array}$ \\
\hline Mekânlardaki aktivitelerin ve etkinliklerin yeterliliği & \\
\hline Mahallenin nüfus yoğunluğu & Yaya trafiği yoğunluğu \\
\hline \multicolumn{2}{|c|}{$\begin{array}{l}\text { Konutlara yürüme mesafesindeki }(400-800 \mathrm{~m}) \text { açık ve yeşil alanların yeterliliği } \\
\text { Kamusal mekânların kalitesi }\end{array}$} \\
\hline
\end{tabular}

\subsubsection{Kullanıcı değerlendirmesi}

Anket çalışmasında örneklem büyüklüğü Çukurambar Mahallesi'nde yaşayan ve çalışan kişi sayısına göre, $n=\left(N t^{2} p q\right) /\left(d^{2}(N-1)+t^{2} p q\right)$ formülüyle hesaplanmıştır (Özdamar, 2003). Bu formülde;

$N$ : Evren birim sayısı, $n$ : Örneklem büyüklüğü

p: Ölçülmek istenen özelliğin gerçekleşme olasılığı 
$q:(1-p)$ ilgilenilen olayın görülme olasılığı

$d$ : kabul edilen örneklem hata oranı

t: \%95 güven düzeyi ( $z$ test değeri 1,96)/\%90 güven düzeyi ( $z$ test değeri için 1,64$) t_{\alpha, s d}=s d$ serbestlik dereceli $t$ dağı̆ımı kritik değerleridir ( $s d=n-1)$. t $\alpha, s d$ kritik değerleri $s d=n-1 \rightarrow 5000$ olduğunda $Z \alpha$ değerlerine eşit alınabilir (Özdamar, 2003).

Örneklem formülünde evren büyüklüğü mahalle nüfusu olan 25.000 kişi, hata payı 0,1 olarak $\% 95$ güven düzeyinde " $t$ " değeri 1,96 alındığında formüle göre yapılan hesaplamada 96 anketin yeterli olduğu bulunmuştur. P ve q değerleri kurulan hipotezin olma ya da olmama durumu ihtimali olması durumundan ötürü birbirine eşit alınmıştır (Yazıcıoğlu ve Erdoğan, 2004). 100 kişiye yapılan anketlerin değerlendirilmesinde sorular, sosyal etkileşim ve erişilebilirliği ilgilendiren maddelere göre sınıflandırılmıştır. Iliş̧ki analizinde kullanılacak farklı değişkenlere sahip veriler, nitel ve nicel ya da normal dağıım gösterip göstermeme durumlarına göre değerlendirilecek test grubu belirlenmiştir.

Ankete katılan bireylerin yaş ve cinsiyete göre dağılımlarında mahalledeki 100 katılımcının \%60'ı kadın \%40'ı erkektir. Alan kullanımlarının artırmak için sosyal çeşitliliğin de olması gerekmektedir (Lambert, 2005). TÜiK (2017) nüfus verilerine göre anket çalışmasında araştırma katılımcılarının dengeli dağılımı durumu erişilebilirlikte, sosyal çeşitliliğin etkisinin değerlendirilmesi açısından olanak sağlamaktadır. Mahalledeki bireylerin \%38'i lisans, \%30'i lise, \%11'i lisansüstü, \%8'i ortaokul, $\% 7$ 'si ön lisans ve \%6'sı ilkokul mezunudur. Anketi cevaplayanların \%52'si çalışmakta, \%48'i öğrenci ya da çalışmamaktadır. Bunların \%29 öğrenci, \%18 kamu görevlisi, \%17 emekli, \%17'si ise özel sektörde çalışanıdır. Korelasyon testinde, meslek grupları ile yaş ve eğitim durumu arasında ilişkisi tespit edilmiştir $(p=0.00)$. Kültürel yapı ve demografik özelliklere ilişkin verilerin dengeli dağılımının sağlanması sosyal etkileşim ve erişilebilirlikteki katkı düzeylerinin test edilmesinde yol göstermiştir.

Alan kullanımları yaş ve cinsiyet grubuna göre orantılı dağılmaktadır. Bireylerin \%42'si yeşil alanı, \%37'si ticaret alanı, \%10'u eğitim tesislerini kullanmaktadır. Parkların ve ticaret alanlarının kullanım derecesi yüksektir. Açık ve yeşil alanları kullanım amaçları sorulduğunda, \%25'i oturmak dinlenmek, \%21'i yürüyüş ve spor yapmak, \%14'ü çocuklarıyla vakit geçirmek, \%12'si piknik yapmak, \%9'u arkadaşlarıyla buluşmak, \%9 ticari alanları kullanmak, \%4 kitap okumak, \%3 bisiklete binmek, \%3 alışveriş yapmak cevabını vermiştir. Mahallede yaşayan bireylerinin açık alan kullanımları önemlidir. Kişilerle yapılan görüşmelerde güven, aidiyet, mahremiyet duygusu gibi psikolojik faktörlerin alan kullanımını ve algılarını yönlendirmede etkili olduğu görülmüştür. Diğer yandan komşuluk ilişkisi hem erişilebilirlik hem de sosyal etkileşim açısından etkilidir. Komşuluk ilişkisini 1'den (çok kötü) 5'e (çok iyi) kadar puanlaması istendiği anket sonuçlara göre komşuluk ilişkisi ve alan kullanım tercileri dağılımı arasında ilişki tespit edilmiştir. Komşuluk ilişkilerinin mekânsal yansımasını araştırmak için, zihin haritalama tekniğinden elde edilen sonuçlara göre; sosyal etkileşim düzeyi yüksek mekânlar ile komşuluk ilişki düzeyleri arasında ilişki vardır. Park, ticaret alanı, eğitim kurumu, dini tesis gibi alan kullanımları olan bireylerin komşuluk ilişkilerinin iyi olma durumları, kötü olma durumlarına göre yüksektir. Mekânsal kalite parametrelerinden kamusal hizmet yeterliliği maddesi ile komşuluk ilişkisi arasında yapılan korelasyon testinde ise $(\mathrm{p}=0.04)$ anlamlılık bulunmuştur.

Sosyal etkileşimi destekleyen etmenler için komşuluk ilişkilerine bakılmıştır. Kişilerin ikamet süresi 1 yıldan az olanlar \%7, 1-5 yıl olanlar \%31, 6-10 yıl olanlar \%18, 10 yıldan fazla olanlar \%44 orandadır. Bireylerin mahallede ikamet etme süresi ile komşuluk ilişkileri arasındaki korelasyon testinde $(P \leq 0,05)$ pozitif yönde bir ilişki bulunmuştur. Mahallede ikamet süresi arttıkça, komşuluk ilişkileri de güçlenmektedir. Komşuluk ilişki düzeyi bireylerin kendi yaptığı değerlendirmeler olup, çok iyi derecede komşuluk ilişkisine sahip bireylerin mahallede 10 yıldan fazla sürede yaşadığı görülmektedir (Şekil 4). 


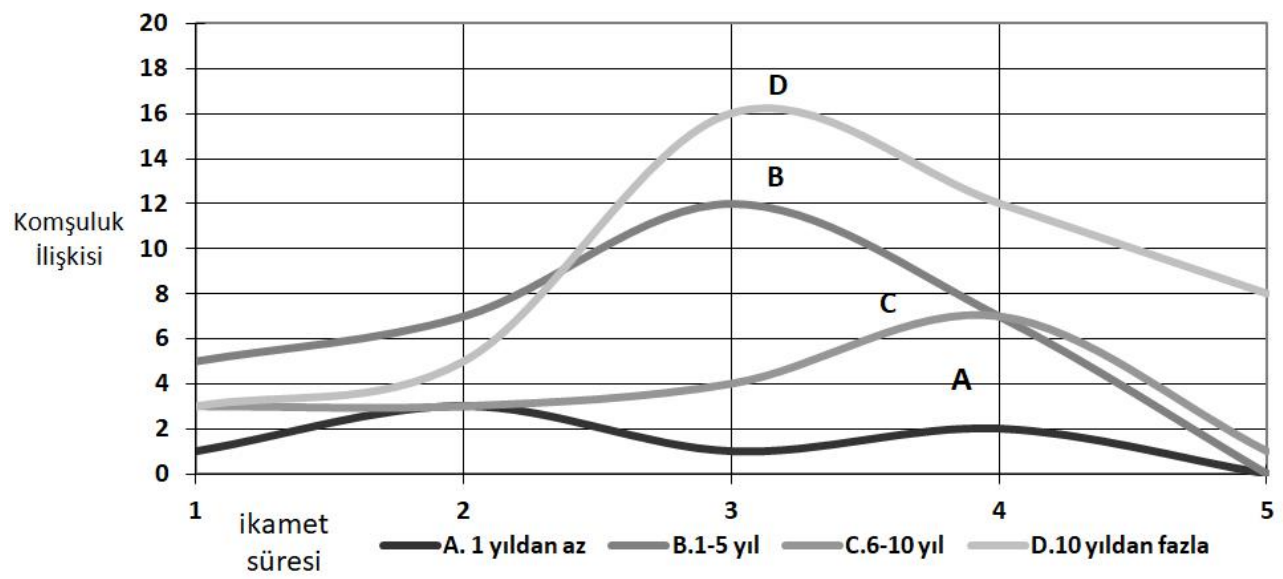

Şekil 4. Bireylerin komşuluk ilişkisi ve ikamet etme süresi arasındaki ilişki

Bireylerin ikamet etme sürelerine göre alan kullanımları da değişim göstermektedir. Mahallede 10 yıldan fazla ikamet eden bireylerin park, spor alanı gibi kentsel açık ve yeşil alan kullanım yüzdeleri diğerlerine göre daha yüksektir. Sosyal etkileşimi destekleyen ikamet süresi ile kullanım ve aktiviteler mekânsal kalite puan değerlendirmesi arasında anlamlılık vardır $(p=0.02)$. Mahallede yaşayan bireylerin ikamet etme süresi arttıkça dış mekânda geçirilen zaman da artmaktadır. Ayrıca kullanılan kamusal alan çeşidi sayısı (park, sokak, çocuk oyun alanı vb.) arttıkça sosyal etkileşim düzeyi de artmaktadır. Erişim mesafesi ile zihin haritalarından elde edilen sosyal etkileşim düzeyi arasındaki ilişkinin değerlendirmesinde, bireylerin evleri ile kullanım alanları arasındaki maksimum yürünebilirlik mesafesine göre etki alanı oluşturulmuştur (Şekil 5). Nicel veriler olarak tanımlanan değerlere normallik durumunda anlamlılık olmamasından dolayı "Kruskall Wallis" testine göre $(p=0,04)$; erişim mesafesi ile bireylerin sosyal etkileşim düzeyi arasında anlamlı bir ilişki bulunmaktadır. Bu anlamlık durumunu incelemek için "Tek yönlü varyans analizi (One-Way Anova)" test değerlerine bakılmıştır. Konut bölgesinden 600 metre uzaklıktaki yürünebilirlik mesafesinde sosyal etkileşim düzeyi ve 1200 1800 metre uzaklıktaki alan kullanımı yüksektir. Konut bölgesinden uzaklaştıkça yürünebilirlik ve sosyal etkileşim düzeyi azalmaktadır. Bireylerin konut alanlarında gideceği mesafede alan kullanımlarına göre dağılımında 1200-1800 metrenin yoğunluk göstermektedir. Sosyal etkileşim düzey derecesi ile alan kullanımları arasında korelasyon testinde $(p=0.00)$ ilişki saptanmıştır. Park, spor alanı, ticaret alanı gibi kamusal alan kullanım çeşitliliği arttıkça sosyallik de artmaktadır.

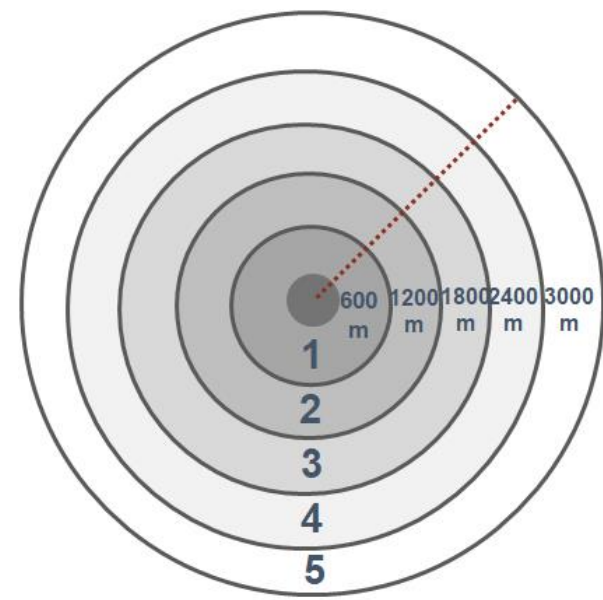

Konut bölgesi

1.0<1. etki alanı $\leq 600 \mathrm{~m}$

$2.600 \mathrm{~m}<2$. etki alanı $\leq 1200 \mathrm{~m}$

$3.1200 \mathrm{~m}<3$. etki alanı $\leq 1800 \mathrm{~m}$

$4.1800 \mathrm{~m}<4$. etki alanı $\leq 2400 \mathrm{~m}$

$5.2400 \mathrm{~m}<5$. etki alanı $\leq 3000 \mathrm{~m}$

Şekil 5. Çukurambar Mahallesi'nde etki alanlarına göre yürünebilirlik mesafeleri

Bireylerin mahallede yaşama sebepleri sorulduğunda önem sırasına göre, kent merkezine yakın olması, konut kalitesinin iyi olması ve yakın çevredeki sosyal imkânların varlığı olarak cevaplanmıştır. Mahalledeki yaşama sebepleriyle mekânsal kalite parametrelerine verdikleri puanlar arasındaki uyumun olması bireylerin düşüncelerini doğrulamada yardımcı olmaktadır. Bu nedenle mekânsal kalite parametrelerinin (erişim ve bağlantılar, kullanım ve aktiviteler, sosyallik, konfor ve imaj) altındaki bileşenler likert ölçekte değerlendirilmiştir. Ölçeğin geçerliliği için yapılan faktör analizinde $(K M O=0,748)$ örneklem faktörleri uygundur. 
Mahalledeki mekânsal kalite parametreleri değerlendirilmesinde, kamusal alanların çeşitliliği ve günün her saatinde kullanılabilirliği, toplu taşımacılık hizmeti, kullanım ve yeterliliği, caziplik ve çekicilik maddelerinde uzlaşma vardır ve iyi (4) puanını almıştır. Erişilebilirlik 2,84 ortalama puan ile \%57, sosyallik 3,11 ortalama puan ile $\% 62$, kullanım ve aktiviteler 3,50 ortalama puan ile $\% 70$, konfor ve imaj 3,28 ortalama puan ile \%66 değerdedir. Mekânsal kalite parametreleri puan ortalaması ise 3,18 değeri ile \%64 oranındadır. Parametreler arasında kullanım ve aktiviteler puanın ve uzlaşma durumunun en yüksek olduğu saptanmıştır. Erişilebilirlik değeri tüm parametreler içinde $\% 57$, sosyallik parametresi ise erişilebilirlik değerine yakın oranda \%62 bulunmaktadır (Şekil 6).

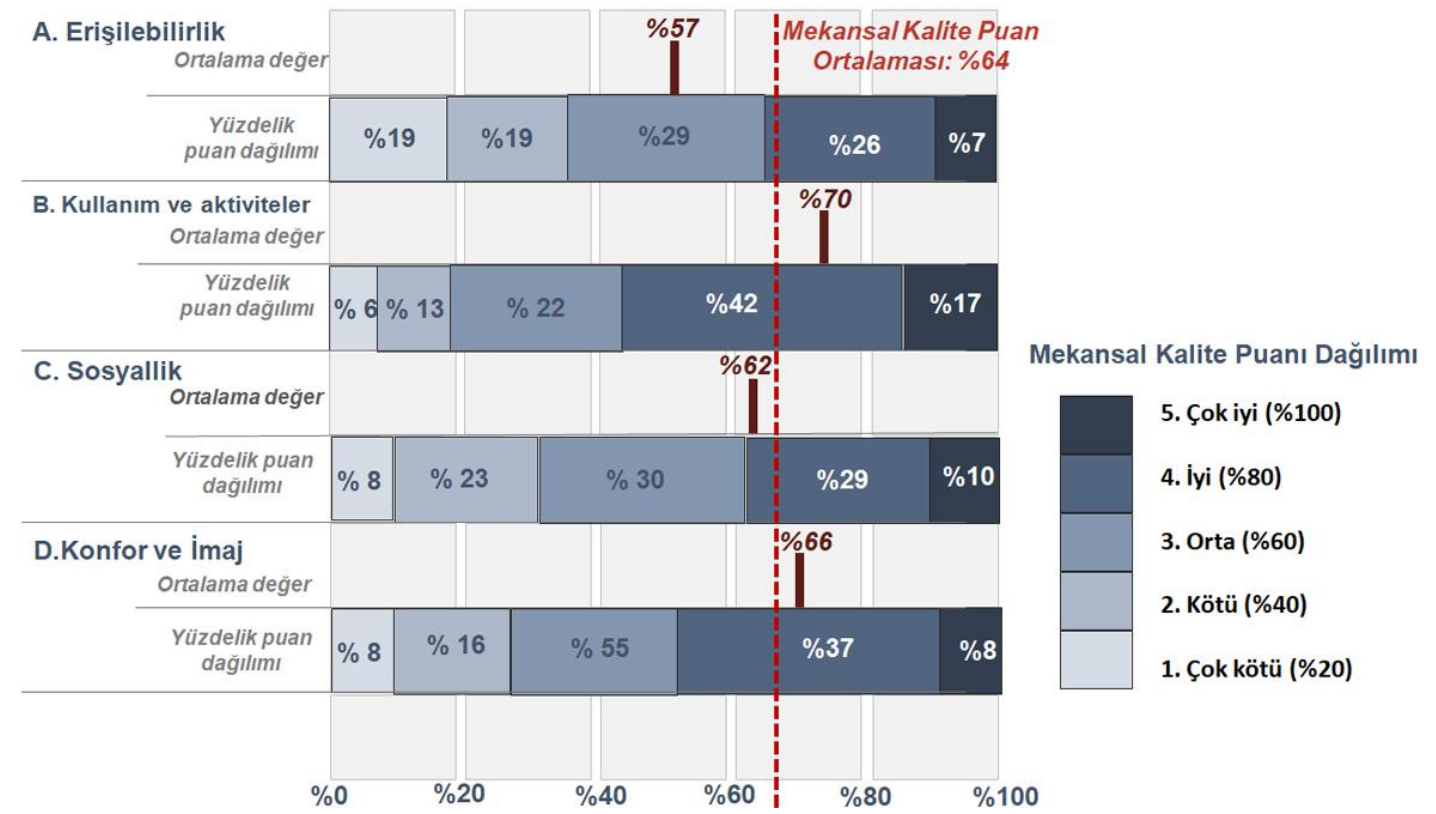

Şekil 6. Anket sonuçlarına göre mekânsal kalite puanının dağılım durumu

Mekânsal kalite parametrelerinin puan ortalamalarının arasındaki ilişkiyi çözmek için basit doğrusal regresyon analizi yapılmıştır. Regresyon testinde Anova tablosuna göre $(p=0,00)$ anlamlılık vardır. Sosyallik değeri ve erişilebilirlik ortalaması birbirinden etkilenmektedir. Bu değerlerin birbirinden ne kadar etkilendiğini ölçmek için incelenen katsayı değeri (R Square) 0,315'tir. Erişilebilirliğin \%31'lik kısmı sosyallik değerinden açıklanmaktadır. Erişilebilirlik ve sosyallik parametrelerinin, diğer mekânsal kalite parametreleri ile ilişkisi hesaplanmış, bunun için tüm parametrelerin regresyon analizi ile ilişkisi çıkarılmıştır (Çizelge 3). Tüm mekânsal kalite parametrelerin birbirleri üzerinde etkisi olup, erişilebilirlik-sosyallik ilişkisi ile sosyallik-konfor ve imaj ilişkisi \%31 oranında en çok etki yüzdesine sahiptir.

Çizelge 3. Mekânsal kalite parametreleri puan ortalamalarının regresyon analiz değerleri

\begin{tabular}{lcccc}
\hline Mekânsal kalite parametreleri ilişkisi & $\begin{array}{c}\text { ilişkinin } \\
\text { Anlamlılı } \\
\text { değeri (p) }\end{array}$ & $\begin{array}{c}\text { Etki } \\
\text { katsayısı:b } \\
\text { (Rsquare) }\end{array}$ & $\begin{array}{c}\text { Etki } \\
\text { Yüzdesi } \\
\text { (\%) }\end{array}$ & $\begin{array}{c}\text { Sabit } \\
\text { değer:a } \\
\text { (Constant) }\end{array}$ \\
\hline 1. Sosyallik-Konfor ve imaj & 0,00 & 0,317 & 31 & 1,122 \\
2. Erişilebilirlik-Sosyallik & 0,00 & 0,315 & 31 & 1,629 \\
3. Kullanım ve aktiviteler-Konfor ve imaj & 0.00 & 0,268 & 26 & 1,276 \\
4. Sosyallik-Kullanım ve aktiviteler & 0,00 & 0,259 & 25 & 0,990 \\
5. Erişilebilirlik-Kullanım ve aktiviteler & 0,00 & 0,231 & 23 & 1,450 \\
6. Erişilebilirlik-Konfor ve imaj & 0,00 & 0,200 & 20 & 1,745 \\
\multicolumn{2}{c}{ p<0.05 ise anlamlı ilişki bulunmaktadır. Regresyon formülü: $\mathbf{y = a + b x}$} & \\
\hline
\end{tabular}




\section{Tartışma ve Sonuç}

Kentlerde nüfus artışı ve buna paralel olarak ihtiyaçların artması sonucu oluşan hızlı kentleşme süreci ekonomik, sosyal ve çevresel pek çok sorunu beraberinde getirmektedir. Bu sorunların çözülebilmesi için özellikle kamusal alanlarda herkesin kullanımına olanak sağlayan kapsayıcı çevrelerin oluşturulması önem kazanmaktadır. Bu bağlamda herkese erişilebilir çevreler sunan ve sosyal etkileşime olanak sağlayan kapsayıcı tasarımın alt bileşenleri olan sosyal etkileşim ve erişilebilirlik ilişkisine ait parametrelerin irdelenmesi kentlerin geleceği için önemlidir. Perry (1929)'a göre kentlerde fiziksel tasarım aracı olan ve sosyal etkileşimin sağlandığı mahalle birimleri, içinde yaşayan bireylerin erişebildikleri kamusal alanlar olarak değerlendirmede dikkate alınmalıdır. Hızlı kentsel dönüşüm süreci geçirmiş, çevresindeki ticaret merkezlerinin etkisi altında yoğun karma alan kullanımlarına sahip olan Ankara Çukurambar Mahallesi'nde bu değiş̧imin etkileri ölçülerek sosyal etkileşimi ve erişilebilirliği geliştirecek tasarım kriterleri ortaya çıkarılmışır. Araştırmada tüm parametrelerin değerlendirmeleri sonucu; erişilebilirlik ile sosyal etkileşim arasında pozitif bir ilişkinin olduğu bulunmuştur. Bu ilişkinin etkisi \%31'dir. Alandaki kamusal mekân kalitesini, sosyallik birinci dereceden etkileyen parametredir. Erişilebilirlik ikinci dereceden etkili mekân kalitesi parametresidir. Çalışma alanındaki kamusal alanlarda sosyal etkileşimi ve erişilebilirliği destekleyen kapsayıcı tasarım kriterleri likert ölçekteki etki ve önem derecesine göre Çizelge 4 'te sıralanmıştır.

Çizelge 4. Sosyal etkileşimi ve erişilebilirliği destekleyen tasarım kriterleri

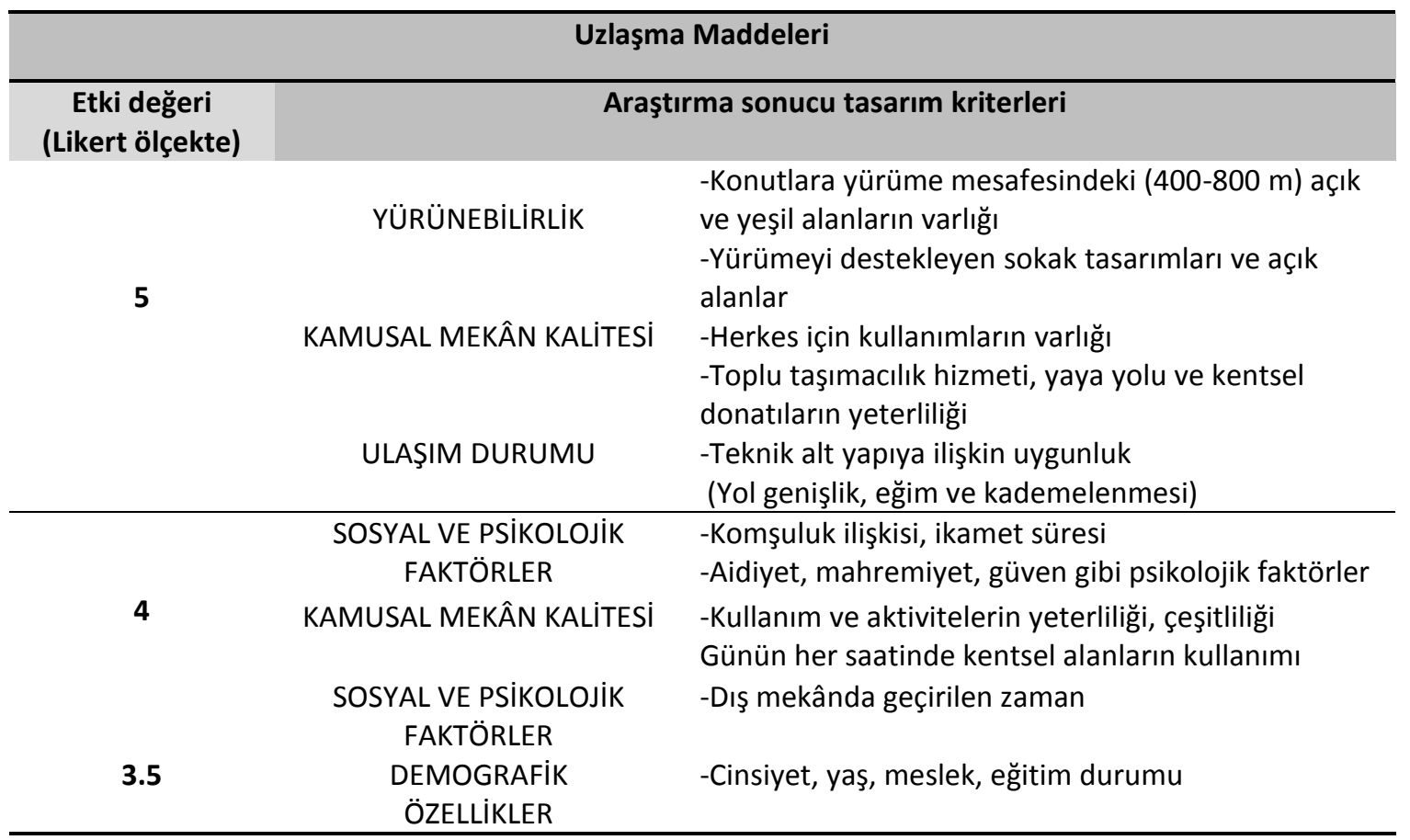

Araştırma sonucuna göre yürünebilirliğin sosyal etkileşim ve erişilebilirliği destekleyen en önemli etmen olduğu ortaya çıkmıştır. Diğer araştırmalarda kent sakinlerinin kamusal alanlara yürüme mesafesindeki yakınlığının sosyal bütünleşmeyi artırdığını (Kaźmierczak, 2013), toplumsal uyum ve etkin arazi kullanımını desteklediğini (Ak, 2018) ve yürümeyi destekleyen sokak tasarımlarının sosyal deneyimleri artırdığını (Ewing ve Clemente, 2013) belirten araştırmalarla benzer sonuçlar alınmıştır. Çalışmada konutlara yürüme mesafesindeki açık ve yeşil alanların sosyal bütünleşmeyi, komşuluk ilişkilerini ve alan kullanımını etkilediği görülmüştür. Çukurambar Mahallesi'nde yürünebilirlik mesafesindeki eğimli alanlarda sosyal etkileşim ve erişilebilirlik değerinin düşük olduğu görülmüştür. ileride yapılan çalışmalarda yürünebilirlik değerlendirilirken arazinin yapısını ortaya koyan eğim gibi özellikler de dikkate alınmalıdır. Kamusal mekân kalitesi yürünebilirlikten sonra sosyal etkileşimi ve erişilebilirliği destekleyen diğer önemli etmendir. Whyte (2000)'in belirlediği sürdürülebilir kamusal mekânsal kalite parametrelerinin sosyal etkileşim ve erişilebilirliği artırdığı bu araştırma sonucunda da desteklenmektedir. Bunlardan herkes için kullanım alanlarının varlığı, toplu taşımacılık hizmeti, yaya yolları, kentsel donatıların uygunluk ve yeterliliği likert ölçekte en çok puanı alan kriterlerdir. Ulaşım durumunda yolların teknik altyapıya ilişkin standartlara uygunluğu kullanıcı ve uzman 
değerlendirmelerinde en çok puanı almıştır. Bu kapsamda sosyal etkileşim ve erişilebilirliğe ilişkin çalışmalarda evrensel standartlara ve yerel yönetimler için ulaşılabilirlik el kitabındaki ilgili standartlara (Kaplan ve diğerleri, 2011) uygunluğun sağlanması esastır.

Araştırma konusuna ilişkin çalışmalara bakıldığında Pulat (1996), Gökçe (2007), Garip (2010) tarafından, komşuluk ilişkisinin sosyal etkileşimin belirleyicisi olduğu ifade edilirken, bu çalışmada komşuluk ilişkisinin sosyal etkileşimin yanı sıra alan kullanımına ve ikamet etme süresine bağlı olduğu ortaya çıkmıştır. Bireylerin yaşadığı yere olan bağıılığının ikamet etme süresine göre değiştiği Anton ve Lawrence, (2014) ve Abass ve Tucker (2018) tarafından da desteklenmektedir. Aidiyet duygusu gibi psikolojik faktörlerin sosyal uyumu ve alan kullanımını etkilediğini belirten Alptekin (2011), Duru (2007) araştırmacılarının ifadelerine ek olarak çalışmada güvenlik faktörünün erişilebilirlik ve sosyal etkileşim açısından önemli olduğu ortaya çıkmıştır. Kamusal alanlarda yapılan çalışmalarda Hesham (2015) aktivite çeşitliliğinin alan kullanımını etkilediğini ve Gehl (1987), Rivlin (1994), Whyte (2000), Nasution ve Zarrah (2012) ise aktivetelerin artmasının sosyal etkileşimi geliştirdiğini belirtmiştir. Araştırmada ise kamusal alanlarda aktivite çeşitliliği ve yeterliliği parametresinin sosyalliğin, günün her saatinde kentsel alanların kullanımı parametresinin ise erişilebilirliğin artırılmasında etkili olduğu görülmüştür. Dış mekânda geçirilen zaman, sosyal etkileşim ve erişilebilirliği destekleyen diğer etmendir. Dış mekânda geçirilen zaman arttıkça bireylerin karşılaşma ve iletişim kurma sıklığı da artmaktadır. Bireylerin yaş, meslek, eğitim durumları gibi demografik özelliklerin sosyal etkileşimi değiştirdiğini gösteren Şensoy (2012) araştırma sonucu yanı sıra çalışma alanındaki değerlendirmede demografik yapının dengeli oranda dağılım sağladığı, bunun da sosyal etkileşimi ve alan kullanımını etkilediği saptanmıştır.

Sonuç olarak bu çalışma, mekân dizimi analiziyle alanın fiziksel erişilebilirliğini sayısal yöntemle değerlendirilerek; yaya hareketi ve alan kullanımlarıyla oluşan sosyal yapı ilişkisine dikkat çekmektedir. Mekân analizi sonuçları, kullanıcıların zihin haritaları ve anket sonuçlarında yoğun kullanılan alanların benzerliği programın doğruluğu ile araştırma sonuçlarını test etmede yol göstermede, fiziksel ve sosyal yapı arasındaki ilişkiyi mekânsal kalite parametreleriyle ölçmede model oluşturmaktadır. Kentsel dönüşüm sürecinin olumsuz etkilerini deneyimleyen Çukurambar Mahallesi'nde sosyal etkileşim ile erişilebilirliği geliştirecek kapsayıcı tasarım kriterlerinin diğer kamusal alanlarda değerlendirilmesi sürdürülebilir kentlere katkı sağlayacaktır.

\section{Teşekkür ve Bilgi Notu}

Bu makale, Ankara Üniversitesi Fen Bilimleri Enstitüsü Peyzaj Mimarlığı Ana Bilim Dalı'nda Prof. Dr. Aysel USLU danışmanlığında Pelin ŞAHIN KÖRMEÇLi tarafından 2019 yılında tamamlanmış olan doktora tezinden üretilmiştir. Makalede, ulusal ve uluslararası araştırma ve yayın etiğine uyulmuştur. Çalışmada etik kurul izni gerekmemiştir.

\section{Yazar Katkısı ve Çıkar Çatışması Beyan Bilgisi}

Makalede tüm yazarlar aynı oranda katkıda bulunmuştur. Herhangi bir çıkar çatışması bulunmamaktadır.

\section{Kaynaklar}

Abass, Z. ve Tucker, R. (2018). White picket fences \& other features of the suburban physical environment: Correlates of neighbourhood attachment in 3 Australian low-density suburbs, Landscape and Urban Planning, 170, 231-240.

Ak, A. (2018). Urban Form and Walkability: The Assesment of Walkability Capacity of Ankara (PhD thesis). Middle East Technical University, City and Regional Planning Department, Natural and Applied Sciences Institute, Ankara.

Alptekin, D. (2011). Toplumsal aidiyet ve gençlik: Üniversite gençliğinin aidiyeti üzerine sosyolojik bir araştırma (Doktora Tezi). Selçuk Üniversitesi, Sosyal Bilimler Enstitüsü, Sosyoloji Anabilim Dalı, Konya.

Anton, C. E. ve Lawrence, C. (2014). Home is where the heart is: The effect of place of residence on place attachment and community participation, Journal of Environmental Psychology, 40, 451461. 
Carr, S., Francis, M., Rivlin, L. ve Stone, A. (1992). Public Space, Cambridge University Press, 400p, New York.

Çanakçıŏlu, N. G. (2016). Pediyatrik Tedavi Mekânlarını Kullanan Bireylerin Mekânsal Algılarının Bilişsel ve Mekân Dizimi Yöntemleriyle Irrdelenmesi (Doktora Tezi). İstanbul Teknik Üniversitesi, Fen Bilimleri Enstitüsü, İstanbul.

Çankaya Belediyesi. (2018). Çankaya Belediyesi Kent Rehberi, Ankara. Erişim Adresi (19.01.2018): https://cbs.cankaya.bel.tr/kentrehberi/

Demir, M. (2006). Müzik ve sosyal etkileşim (Yüksek Lisans Tezi). İstanbul Üniversitesi, Sosyal Bilimler Enstitüsü, İstanbul.

Eisner, S., Gallion, A. ve Eisner, S. (1993). The Urban Pattern, Van Nostrand Reinhold, 641p, New York.

Erdönmez, M. E. ve Akı, A. (2008). Açık Kamusal Kent Mekânlarının Toplum iliş̧kilerindeki Etkileri, Megaron, 1(1), 67.

Evcil, N. A. (2014). Herkes için Tasarım Evrensel Tasarım, Boğaziçi Yayınları, 143s, İstanbul.

Ewing, R. ve Clemente, O. (2013). Measuring urban design: Metrics for livable places, Island Press, 200p, Washington.

Garip, S. B. (2010). Dışa Kapalı Konut Yerleşimlerinde Sosyal ihtiyaçların Fiziksel Ve Sosyal Etkileşim Çerçevesinde Irdelenmesi (Doktora Tezi). İstanbul Teknik Üniversitesi, Fen Bilimleri Enstitüsü, İstanbul.

Gehl, J. (1987). Life Between Buildings: Using Public Space, Arkitektens Forlag, 216p, Copenhagen.

Goličnik, B. ve Thompson, C. W. (2010). Emerging relationships between design and use of urban park spaces, Landscape and Urban Planning, 94(1), 38-53.

Gökçe, Ş. (2007). Sosyal Etkileşimi Geliştirecek Peyzaj Tasarımı Üzerine Bir Araştırma: Çukurambar Mahallesi Örneği (Yüksek Lisans Tezi). Fen Bilimleri Enstitüsü, Ankara Üniversitesi, Ankara.

Gökten, M. (1991). Toplu Konutlarda İnsan-Mekân Illişkileri (Doktora Tezi). Ege Üniversitesi, Sosyal Bilimler Enstitüsü, İzmir.

Hacıhasanoğlu, I. (2003). Evrensel Tasarım, Tasarım+ kuram dergisi, 2(3), 93-101.

Hesham, E. O. (2015). Small Town Community Social Interaction in Public Spaces (PhD Thesis). Faculty of Built Environment Universiti Teknologi, Malaysia.

Hildebrand, F. (1999). Designing Toward the More Sustainable Urban Form. Spon Press, 160 p, London and New York.

Hillier, B. ve Hanson, J. (1984) The Social Logic of Space, Cambridge University Press, 296p, Great Britain.

Johnson, D. L. (2002). Origin of the Neighbourhood Unit, Planning Perspectives, 17(3), 227-245.

Kaplan, H. ve Öztürk, M. (2004). Engelliler, Kamu Mekânı ve Engelsiz Tasarım: Kamusal iç̧ Mekânlarda İrdelenmesi İçin Bir Çerçeve, Planlama Dergisi, 2(4), 67-74.

Kaplan, H., Yüksel, Ü., Gültekin, B., Güngör, C., Karasu, N., Çavuş, M. (2011). Yerel Yönetimler İçin Ulaşılabilirlik Temel Bilgiler Teknik El Kitabı. T.C. Aile ve Sosyal Politikalar Bakanlığı Özürlü ve Yaşlı Hizmetleri Genel Müdürlüğü Yayınları, 125 s. Ankara.

Kaymaz, M. K. (2015). Eğitim Yapılarında Bedensel Engellilere Yönelik Engelsiz Tasarım, Selçuk-Teknik Dergisi, 14(2), 238-250.

Kaźmierczak, A. (2013). The contribution of local parks to neighbourhood social ties, Landscape and Urban Planning, 109(1), 31-44.

Lambert, K. (2005). Critical Evaluation of Livability in Garisson Woods (A master thesis). University of Calgary, Faculty of Environmental Design, Canada.

Lang, J. T. (1987). Creating architectural theory: The role of the behavioral sciences in environmental design, Van Nostrand Reinhold, 205p, New York.

Lynch, K. (2010). Kent imgesi, Türkiye İş Bankası Kültür Yayınları, 215s, İstanbul.

Nasution, A. D. ve Zahrah, W. (2012). Public open space privatization and quality of life, case study Merdeka Square Medan, Procedia-Social and Behavioral Sciences, 36, 466-475.

Özbek, M. (2007). Fizik Mekân Kurgularının Sosyal iliş̧kiler Üzerinden Arnavutköy Yerleşimi Bütününde Mekân Dizimi (Space Syntax) Yöntemi ile Incelenmesi (Doktora Tezi). Mimar Sinan Güzel Sanatlar Üniversitesi, Fen Bilimleri Enstitüsü, İstanbul. 
Özbil, A. Yeşiltepe, D. ve Argin, G. (2015). Modeling walkability: The effects of street desing, streetnetwork configuration and land-use on pedestrian movement, $A$ / Z ITU Journal of the Faculty of Architecture, (12)3, 189-207.

Özdamar, K. (2003). Modern bilimsel araştırma yöntemleri, Kaan Kitabevi Yayınları, 228s, Eskişehir.

Özyılmaz, P. (2009). Kentsel açık alan tasarımının değerlendirilmesi için mekân dizimi yaklaşımı (Yüksek lisans tezi). Gebze Teknik Üniversitesi, Şehir ve Bölge Planlama Anabilim Dalı, Mühendislik ve Fen Bilimleri Enstitüsü, Gebze.

Perry, C. (1929). The Neighborhood Unit, a Scheme of Arrangement for the Family-Life Community. Monograph one, Neighborhood and Community Planning, Regional Plan of New York and Its Environs, 140p, New York.

Pulat, G. (1996). Toplu Konutlarda Kullanııı Memnuniyetinin Değerlendirilmesi, Yerleşmelerde Sosyal Etkileşimin İrdelenmesi, Konut Araştırmaları Sempozyumu, T.C. Başbakanlık Toplu Konut İdaresi Başkanlığı, Konut Araştırmaları Dizisi:1, Ankara, s.269-287.

Project for Public Spaces (2019). The Place Diagram. Erişim Adresi (4 Ocak 2019): http://www.pps.org/reference/what_is_placemaking/

Southworth, M. ve Owns, P. M. (1993). Evolving metropolis: studies of community, neighbourhood, and street form at the urban edge, Journal of the Amerikan Planning Association, 59(3), 87-217.

Rivlin, L.G. (1994). Public spaces and public life in urban areas. In Neary, S.J., Symes, M.S., Brown, F.E. (Eds.). The Urban Experience: A People-Environment Perspective, (ss. 289-296). London: Taylor \& Francis Group.

Southworth, M. (2005). Designing the Walkable City. Journal of Urban Planning and Development, 131(4), 246-257.

Stevens, Q. (2006). The shape of urban experience: a reevaluation of Lynch's five elements, Environment and planning B: Planning and design, 33(6), 803-823.

Şahin, A. E. (2001). Eğitim araştırmalarında delphi tekniği ve kullanımı, Hacettepe Üniversitesi Eğitim Fakültesi Dergisi, 20(20), 215-220.

Şahin, A. E. (2009). Türkiye'de Ilköğretim Okulu Müdürlüğünün Bir Meslek Olarak Mevcut Durumu: Bir Delphi Çalışması, Pamukkale Üniversitesi Eğitim Fakültesi Dergisi, 26(26), 125-136.

Şensoy, N. ve Karadağ, A. (2012). Sosyal etkileşimin komşuluk düzeyinde geliştirilmesine yönelik bir araştırma: Ankara TOKi Atakent Sitesi örneği, Inönü Üniversitesi Sanat ve Tasarım Dergisi, 2(1), 279-289.

Thomas, M. (1991). The demise of public space, in: V. Nadin \& J. Doak (Eds) Town Planning Responses to City Change, (ss. 209-224). Aldershot: Avebury.

Tutal, O. (1999). Toplu Konut Alanlarında Biçimsel Yapının Mekân Dizimi Yöntemiyle Değerlendirilmesi Eskişehir Örneği (Doktora Tezi). İstanbul Teknik Üniversitesi, Şehir ve Bölge Planlama Anabilim Dalı, İstanbul.

TÜik (2017). Çukurambar Mahallesi nüfusunun yaş ve cinsiyet durumuna göre dağılımı, Türkiye İstatistik Kurumu, Bilgi-Dağıtım İletişim Daire Başkanlığı Veri Tabanı.

Uzgören, G. ve Erdönmez, M. E. (2017). Kamusal Açık Alanlarda Mekân Kalitesi ve Kentsel Mekân Aktiviteleri Illişkisi Üzerine Karşılaştırmalı Bir İnceleme, Megaron, 12(1), 41-56.

Whyte, W. H. (2000). The Social Life Of Small Urban Spaces, Common Ground? Ed.: A.M. Orum and Z.P. Neal, Readings and Reflections on Public Space, (ss. 32-39). New York, Routledge.

Yazıcıoğlu, Y. ve Erdoğan, S. (2004). SPSS uygulamalı bilimsel araştırma yöntemleri, Ankara, Detay yayıncilık, 448s, Ankara.

Zeliff, N. D. ve Heldenbrand, S. S. (1993). What Has Being Done In The International Business Curriculum?, Business Education Forum, 48 (1), 23-25. 